\title{
Persistent Metabolic Abnormalities in Diabetes in the Absence of Glucagon
}

\author{
A.J. Barnes, S. R. Bloom, K. Mashiter, K. G. M. M. Alberti, P. Smythe and D. Turnell \\ Department of Endocrinology, Royal Postgraduate Medical School, Hammersmith Hospital, London and Department of Chemical \\ Pathology and Human Metabolism, General Hospital, Southampton, England
}

\begin{abstract}
Summary. In order to investigate the contribution of glucagon to the abnormalities of carbohydrate and lipid metabolism in diabetes, hormones and metabolites were measured in response to IV arginine in 5 juvenile onset (control) diabetics and 5 totally pancreatectomised subjects. In the basal state, both control diabetics and pancreatectomised patients showed abnormally elevated levels of plasma glucose, blood 3-hydroxybutyrate, glycerol and plasma free fatty acids (NEFA), although no glucagon was detectable in the plasma of the pancreatectomised subjects. Blood concentrations of the gluconeogenic precursors alanine and glycerol were higher in the pancreatectomised patients than in the diabetics. Following infusion of arginine, the rise in glucagon observed in the diabetics was accompanied by a significant increase in plasma glucose and a fall in blood lactate when compared to the pancreatectomised subjects. In spite of the rise in glucagon in the control diabetics, no significant change was found in the concentrations of ketone bodies, glycerol or NEFA. Thus glucagon does not seem to have a primary role in producing the metabolic abnormalities of diabetes.
\end{abstract}

Key words: Hyperglucagonaemia, suppression of plasma glucagon, arginine infusion, pancreatectomised subjects, diabetic controls, glucose, 3-hydroxybutyrate, glycerol, alanine, lactate, pyruvate.

Hyperglucagonaemia has recently been suggested as an essential factor in the pathogenesis of diabetes mellitus [20, 23]. This hypothesis is supported by the fact that administration of pharmacological doses of glucagon to patients with juvenile onset diabetes has been shown to exaggerate many of the biochemical abnormalities of this disorder [17, 21]. In addition, suppression of glucagon release in diabetics by somatostatin was observed to retard the development of ketoacidosis following deprivation of insulin [12]. These and other investigations suggested that improvement in diabetic control might be achieved by therapeutic reduction of glucagon secretion. In order to examine further this possibility, we have investigated carbohydrate and lipid metabolism in 5 insulin dependant diabetic patients and 5 totally pancreatectomised subjects who lacked measurable quantities of circulating plasma glucagon.

\section{Materials and Methods}

\section{Patients}

5 subjects who had undergone total surgical pancreatectomy and 5 age and sex matched insulindependant diabetic patients were investigated (Table 1). The 5 pancreatectomised patients were receiving significantly less insulin $(P<0.05)$ than the insulindependant diabetics $(0.44$ and 0.67 units $/ \mathrm{kg}$ body weight $/ 24 \mathrm{~h}$ ). Plasma ' $\mathrm{C}$ ' peptide levels were undetectable in all individuals either in the fasting state or after IV arginine. No patient had detectable levels of glucagon antibodies.

\section{Test Procedures}

Patients were investigated after a $14 \mathrm{~h}$ fast and before their normal morning dose of insulin. An indwelling cannula was inserted into a vein in the antecubital fossa of each arm and each patient was rested in the sitting position for a minimum of $45 \mathrm{~min}$ before baseline blood samples were taken at $-15,-5 \mathrm{~min}$ and zero time. Arginine hydrochloride $(0.5 \mathrm{~g} / \mathrm{kg}$ body weight) was then infused into the opposite arm at a 
Table 1. Clinical details of 5 pancreatectomised patients and 5 insulin-dependent diabetic controls

\begin{tabular}{|c|c|c|c|c|c|}
\hline Patients & Sex & $\begin{array}{l}\text { Age } \\
(\mathrm{yr})\end{array}$ & $\begin{array}{l}\% \text { of ideal } \\
\text { weight }\end{array}$ & $\begin{array}{l}\text { Insulin } \\
\text { treatment } \\
\text { (units) }\end{array}$ & $\begin{array}{l}\text { Total pancreatectomy } \\
\text { reason and date }\end{array}$ \\
\hline \multicolumn{6}{|c|}{ Pancreatectomised } \\
\hline J D & $M$ & 34 & 63 & $\begin{array}{l}\text { Sol } 12 \text { a m } \\
\text { Sol } 8 \text { p m }\end{array}$ & Chronic pancreatitis 1974 \\
\hline MH & $\mathrm{F}$ & 40 & 73 & $\begin{array}{l}\text { Sol } 6 \mathrm{am} \\
\text { Sol } 4 \mathrm{p} \mathrm{m}\end{array}$ & Chronic pancreatitis 1973 \\
\hline R B & $\mathrm{F}$ & 49 & 92 & $\begin{array}{l}\text { Sol } 16 \text { a m } \\
\text { Sol } 12 \text { p m }\end{array}$ & $\begin{array}{l}\text { Well-differentiated } \\
\text { adenocarcinoma of } \\
\text { pancreas; May } 1975\end{array}$ \\
\hline F W & $\mathrm{F}$ & 60 & 99 & $\begin{array}{l}\text { Sol } 10 \text { a m } \\
\text { NPH } 10 \text { a m }\end{array}$ & $\begin{array}{l}\text { Benign pancreatic } \\
\text { cyst; } 1969\end{array}$ \\
\hline G B & M & 67 & 54 & $\begin{array}{l}\text { Sol } 10 \text { a m } \\
\text { Sol } 8 \mathrm{p} \mathrm{m}\end{array}$ & $\begin{array}{l}\text { Well-differentiated } \\
\text { adenocarcinoma of } \\
\text { pancreas; } 1974\end{array}$ \\
\hline \multicolumn{6}{|c|}{ Diabetic controls } \\
\hline J M & $\mathbf{M}$ & 29 & 99 & $\begin{array}{l}\text { Sol } 24 \text { a m } \\
\text { NPH } 8 \text { a m } \\
\text { Sol } 24 \text { p m }\end{array}$ & \\
\hline M W & $\mathrm{F}$ & 37 & 106 & $\begin{array}{l}\text { Sol } 24 \text { a m } \\
\text { PZI } 12 \text { a m }\end{array}$ & \\
\hline V B & $\mathrm{F}$ & 48 & 96 & $\begin{array}{l}\text { Sol } 36 \text { a m } \\
\text { PZI } 8 \text { a m }\end{array}$ & \\
\hline $\mathrm{KP}$ & $\mathrm{F}$ & 56 & 120 & $\begin{array}{l}\text { Sol } 16 \text { a m } \\
\text { NPH } 16 \text { a m }\end{array}$ & \\
\hline $\mathrm{J} \mathrm{M}$ & $\mathbf{M}$ & 60 & 97 & $\begin{array}{l}\text { Sol } 24 \text { a m } \\
\text { PZI } 16 \text { a m }\end{array}$ & \\
\hline
\end{tabular}

constant rate for $30 \mathrm{~min}$ and further blood samples were taken at 5, 10, 20, 25, 30, 40 and $60 \mathrm{~min}$. Blood samples were assayed for glucagon, growth hormone, cortisol, glucose, glycerol, free fatty acids, acetocetate, 3-hydroxybutyrate, alanine, pyruvate and lactate. Informed consent was obtained from all patients for the procedures carried out in the study.

\section{Assays}

Plasma pancreatic glucagon was measured by radioimmunoassay with a pancreatic glucagon-specific (C terminal reacting) antiserum $[1,4]$. Plasma growth hormone was measured by radioimmunoassay [15] using WHO 1st IRP $(66 / 217)$ as standard. Plasma cortisol was measured by competitive protein binding [3]. Plasma glucose was assayed by an automated glucose oxidase method [13]. Blood lactate [16], pyruvate [5], 3-hydroxybutyrate [24], glycerol [10] and alanine [25] were measured by enzymatic methods and plasma non-esterified fatty acids (NEFA) were measured by a radioactive cobalt method [14]. Plasma for glucagon, growth hormone, cortisol and NEFA assays was separated immediately after blood sampling and stored at $-20^{\circ} \mathrm{C}$ so that all samples could be assayed in the same batch.

\section{Statistics}

Student's paired and non-paired $t$ tests were used to assess the significance of changes in hormones and metabolites.

\section{Results}

Plasma and blood concentrations of hormones and metabolites in the fasting state, at the end of a $30 \mathrm{~min}$ infusion of arginine and at $60 \mathrm{~min}$ are shown in Table 2.

\section{Initial Fasting Values}

Hormones. Fasting levels of plasma glucagon were elevated in the diabetic controls but not significantly different from zero in the pancreatectomised subjects. The increase in plasma growth hormone in the diabetics just failed to reach statistical significance when compared with the pancreatectomised subjects. Levels of plasma cortisol were within the normal laboratory range in all subjects.

Metabolites. Plasma glucose, NEFA and blood glycerol and 3-hydroxybutyrate were increased in both 
Table 2. Plasma and blood concentrations of hormones and metabolites ( \pm SEM $)$ in 5 pancreatectomised subjects and 5 insulin-dependent diabetic controls, in the fasting state and after intravenous infusion of arginine

\begin{tabular}{|c|c|c|c|c|c|c|}
\hline \multirow{2}{*}{$\begin{array}{l}\text { Hormones and metabolites } \\
\text { with Mean } \pm \text { SEM for } \\
\text { healthy adults } \\
\text { Glucagon }\end{array}$} & \multirow{2}{*}{$\frac{\begin{array}{c}\text { Time } \\
\text { mins }\end{array}}{0}$} & \multicolumn{2}{|c|}{$\begin{array}{l}\text { Pancreatectomised } \\
\text { subjects }\end{array}$} & \multicolumn{2}{|c|}{$\begin{array}{l}\text { Diabetic } \\
\text { controls }\end{array}$} & \multirow{2}{*}{$\begin{array}{l}\begin{array}{l}\text { Significance } \\
\text { of } \\
\text { difference }\end{array} \\
\mathrm{P}<0.02\end{array}$} \\
\hline & & 1.3 & \pm 0.6 & 17.2 & \pm 5.3 & \\
\hline $\mathrm{pmol} / 1$ & 30 & 0.3 & \pm 0.3 & 93.0 & $\pm 4.5^{\mathrm{b}}$ & $\mathrm{P}<0.001$ \\
\hline$(7.0 \pm 0.6)$ & 60 & 1.2 & \pm 0.6 & 25.2 & \pm 2.6 & $\mathbf{P}<0.001$ \\
\hline Growth hormone & 0 & 3.8 & \pm 1.5 & 8.4 & \pm 1.5 & NS \\
\hline $\mathrm{mu} / \mathrm{l}$ & 30 & 13.6 & \pm 5.8 & 15.9 & \pm 5.4 & NS \\
\hline$(<5)$ & 60 & 12.5 & \pm 3.4 & 17.0 & \pm 3.3 & NS \\
\hline Cortisol & 0 & 228 & \pm 60 & 188 & \pm 44 & NS \\
\hline $\mathrm{nmol} / 1$ & 30 & 185 & \pm 57 & 163 & \pm 46 & NS \\
\hline$(100-500)$ & 60 & 176 & \pm 52 & 164 & \pm 45 & NS \\
\hline Glucose & 0 & 13.9 & \pm 3.0 & 21.6 & \pm 1.2 & $\mathrm{P}<0.05$ \\
\hline $\mathrm{mmol} / \mathrm{l}$ & 30 & 13.1 & \pm 3.1 & 23.3 & \pm 1.3 & $P<0.02$ \\
\hline$(4.3 \pm 0.2)$ & 60 & 13.1 & \pm 3.0 & 24.4 & $\pm 1.6^{\mathrm{a}}$ & $\mathrm{P}<0.02$ \\
\hline 3 hydroxy butyrate & 0 & 0.56 & \pm 0.18 & 0.84 & \pm 0.22 & NS \\
\hline $\mathrm{mmol} / \mathrm{l}$ & 30 & 0.46 & \pm 0.14 & 0.88 & \pm 0.20 & NS \\
\hline$(0.03 \pm 0.01)$ & 60 & 0.45 & \pm 0.15 & 1.02 & \pm 0.23 & NS \\
\hline NEFA & 0 & 1.90 & \pm 0.28 & 1.71 & \pm 0.51 & NS \\
\hline $\mathrm{mmol} / \mathrm{I}$ & 30 & 1.32 & \pm 0.15 & 1.58 & \pm 0.30 & NS \\
\hline$(0.76 \pm 0.08)$ & 60 & 1.48 & \pm 0.18 & 1.50 & \pm 0.16 & NS \\
\hline Glycerol & 0 & 0.25 & \pm 0.01 & 0.15 & \pm 0.03 & $P<0.02$ \\
\hline $\mathrm{mmol} / \mathrm{l}$ & 30 & 0.22 & \pm 0.01 & 0.15 & \pm 0.02 & $P<0.02$ \\
\hline$(0.07 \pm 0.01)$ & 60 & 0.23 & \pm 0.03 & 0.15 & \pm 0.03 & NS \\
\hline Alanine & 0 & 0.56 & \pm 0.11 & 0.24 & \pm 0.03 & $P<0.05$ \\
\hline $\mathrm{mmol} / \mathrm{l}$ & 30 & 0.56 & \pm 0.11 & 0.23 & \pm 0.03 & $\mathrm{P}<0.05$ \\
\hline$(0.29 \pm 0.02)$ & 60 & 0.59 & \pm 0.11 & 0.25 & \pm 0.03 & $P<0.02$ \\
\hline Lactate & 0 & 1.06 & \pm 0.35 & 0.80 & $\pm 0,07$ & NS \\
\hline $\mathrm{mmol} / 1$ & 30 & 1.06 & \pm 0.36 & 0.71 & \pm 0.04 & NS \\
\hline$(0.72 \pm 0.04)$ & 60 & 1.19 & \pm 0.52 & 0.69 & $\pm 0.04^{\mathrm{b}}$ & NS \\
\hline Pyruvate & 0 & 0.06 & \pm 0.003 & 0.078 & \pm 0.007 & NS \\
\hline $\mathrm{mmol} / \mathrm{l}$ & 30 & 0.06 & \pm 0.004 & 0.06 & \pm 0.004 & NS \\
\hline$(0.072 \pm 0.005)$ & 60 & 0.06 & \pm 0.005 & 0.05 & \pm 0.005 & NS \\
\hline
\end{tabular}

Values with asterisks indicate a significant change in comparison with basal values

${ }^{\text {a }} \mathrm{P}<0.05$

${ }^{\circ} \mathrm{P}<0.02$

diabetics and pancreatectomised subjects in comparison with values for healthy adults (Table 2). Fasting blood levels of the gluconeogenic precursors alanine and glycerol were significantly higher in the pancreatectomised subjects than in the diabetics $(\mathrm{p}<$ 0.05 and $p<0.02$ ). Blood levels of lactate and pyruvate were normal in both groups.

There was no indication in either the diabetics or the pancreatectomised subjects that basal levels or changes in metabolites were related to body weight or to differing degrees of hyperglycaemia.

\section{Changes Following Arginine}

Hormones. Plasma glucagon rose to maximum at 25 min $(\mathrm{p}<0.02)$ during infusion of arginine in the diabetic controls but remained undetectable in the pancreatectomised subjects. Neither group showed a significant change in growth hormone or cortisol following arginine.
Metabolites. In the diabetics, plasma glucose rose significantly after arginine ( $p<0.05$ at $60 \mathrm{~min})$ but did not change in the pancreatectomised subjects. Of the other metabolites, only lactate showed a significant change, falling in the diabetics ( $p<0.02$ at $60 \mathrm{~min}$ ) but remaining unchanged in the pancreatectomised subjects.

\section{Discussion}

The finding of elevated fasting levels of glucose, 3-hydroxybutyrate, NEFA and glycerol in pancreatectomised subjects despite significantly undetectable circulating glucagon indicates that glucagon is not an essential factor in the aetiology of diabetes. In addition, elevation of glucagon by arginine infusion in the diabetics to plasma levels similar in magnitude to those occurring after a protein-rich meal resulted only in a significant rise in plasma glucose and a fall in 
blood lactate. Thus fluctuations in plasma glucagon within the physiological range would be unlikely to result in the changes in levels of metabolites that have been observed following administration of large pharmacological doses of this hormone $[17,21]$. The failure of physiological changes in glucagon to influence circulating levels of metabolites has previously been described [2, 22].

Fasting blood levels of the gluconeogenic precursors alanine and glycerol were significantly higher in the pancreatectomised patients than in the diabetics. Blood levels of these precursors reflect a balance between muscle release which is inhibited by insulin and hepatic uptake which is enhanced by glucagon [11]. Their increase in the pancreatectomised patients could, therefore, have resulted from a decreased clearance from the circulation. The rise of glucagon in the diabetics after arginine was, however, not followed by a measurable reduction in either alanine or glycerol.

The main objective in improving blood glucose concentrations in diabetic patients by suppressing glucagon would be to prevent the onset of diabetic complications and to improve the clinical manifestations of poor diabetic control. Although reports of total pancreatectomy (usually for malignancy) have appeared in the literature since 1944 [19], few recipients of this operation have survived long enough to evaluate the effect of lack of glucagon on the incidence of diabetic complications. However, diabetic retinopathy was noted in one patient after 3 years [6] and diabetic glomerulosclerosis in another after 8 years [9]. Pancreatectomised subjects continue to suffer from the symptoms of poor diabetic control since they are particularly at risk from hypoglycaemia [18]. In addition, diabetic ketoacidosis has been reported in these patients $[7,8]$ demonstrating that hyperglycaemia and hyperketonaemia can still occur in situations of inadequate insulin replacement.

The persistence of diabetes in the absence of glucagon in pancreatectomised subjects and indeed the relatively mild diabetes seen in the glucagonoma syndrome where enormously elevated plasma levels of this hormone have been observed, suggest that insulin lack rather than glucagon excess is the primary factor in the aetiology of diabetes. Suppression of glucagon does little to correct many of the metabolic abnormalities seen in this condition and may indeed result in new features such as accumulation of gluconeogenic precursors in the circulation.

Acknowledgements. We are very grateful to Dr C. Binder for the measurement of ' $\mathrm{C}$ ' peptide and to Miss
C. Soveny, Mr D. Barrett and Miss S. Bevan for the measurement of glucagon, growth hormone and cortisol respectively. We would like to thank Dr Arnold Bloom, Prof. C. G. Clark, Mr A. Lewis, Dr D. N. Phear, Mr J. B. Pearson, Dr D. L.H. Patterson and Dr M. Sarner for permission to investigate their patients. We also thank the British Diabetic Association for financial assistance.

\section{References}

1. Barnes, A.J., Bloom, S.R.: Pancreatectomised man: a model for diabetes without glucagon. Lancet 1976 I, 219-221

2. Barnes, A.J., Bloom, A., Crowley, M.F., Tuttlebee, J.W., Bloom, S. R., Alberti, K.G.M.M., Smythe, P., Turnell, D.: Is glucagon important in stable insulin-dependant diabetics? Lancet 1975 II, 734-737

3. Beardwell, C.G., Burke, C.W., Cope, C.L.: Urinary free cortisol measured by competitive protein binding. J. Endocr. 42, 79-89 (1968)

4. Bloom, S.R.: Hormones of the gastrointestinal tract. Brit. med. Bull. 30, 62-67 (1974)

5. Bucher, T., Czok, R., Lamprecht, W., Latzko, E.: Methods of enzymatic analysis (ed. H.-U. Bergmeyer), p. 324. New York: Academic Press 1963

6. Burton, T.Y., Kearns, T.P., Rynearson, E.H.: Diabetic retinopathy following total pancreatectomy. Proc. Staff. Meet. Mayo Clin. 32, 735-739 (1957)

7. Creutzfeldt, W., Kümmerle, F., Kern, E.: Beobachtungen an vier Patienten mit totaler Pancreatektomie wegen eines Karzinoms des Pankreas. Dtsch. med. Wschr. 84, 541-549 (1959)

8. Dixon, C.F., Comfort, M.W., Lichtman, A.L., Benson, R.E.: Total pancreatectomy for carcinoma of the pancreas in a diabetic person. Metabolic studies. Arch. Surg. 52, 619-639 (1946)

9. Doyle, A.P., Balgerzak, S.P., Jeffrey, W.L.: Fatal diabetic glomerulosclerosis after total pancreatectomy. New Engl. J. Med. 270, 623-624 (1964)

10. Eggstein, M., Kreutz, F.H.: Eine neue Bestimmung der Neutralfette. Klin. Wschr. 44, 262-267 (1966)

11. Exton, J.H., Mallette, L.E., Jefferson, L.S.: The hormonal control of hepatic gluconeogenesis. Recent Progr. Hormone Res. 26, 411-457 (1970)

12. Gerich, J.E., Lorenzi, M., Bier, D.M., Schneider, V., Tsalikian, E., Karam, J.H., Forsham, P.H.: Prevention of human diabetic ketoacidosis by somatostatin. Evidence for an essential role of glucagon. New Engl. J. Med. 292, 985-989 (1975)

13. Gutteridge, J., Wright, E. B.: A simple automated guaiacomb glucose oxidase method. J. med. Lab. Technol. 25, 385-386 (1968)

14. Ho, R.J., Meng, H.C.: A simple and ultra-sensitive method for determination of free fatty acid by radiochemical assay. Analyt. Biochem. 31, 426-436 (1969)

15. Hartog, M., Gaafar, M.A., Meisser, B., Fraser, T.R.: Immunoassay of serum growth hormone in acromegalic patients. Brit. med. J. 1964 II, 1229-1232

16. Hohorst, H.J., Kreutz, F.H., Bücher, T.: Über Metabolit und Metabolit-Konzentrationen der Leber der Ratte. Biochem. Z. 332, 18-46 (1959) 
17. Liljenquist, J.E., Bomboy, J.D., Lewis, S.B., Sinclair-Smith, B. C., Felts, P. W., Lacy, W.W., Crofford, O. B., Liddle, G.W.: Effects of glucagon on lipolysis and ketogenesis in normal and diabetic men. J. clin. Invest. 53, 190-197 (1974)

18. McCullagh, E.P., Cook, J.R., Shirley, E. K.: Diabetes following total pancreatectomy, clinical observations of ten cases. Diabetes 7, 298-307 (1958)

19. Priestley, J.T., Comfort, M.W., Radcliffe, J.: Total pancreatectomy for hyperinsulinism due to an islet-cell adenoma. Ann. Surg. 119, 211-221 (1944)

20. Sakurai, H. Dobbs, R.E., Unger, R.H.: The role of glucagon in the pathogenesis of the endogenous hyperglycaemia of diabetes mellitus. Metabolism 24, 1287-1297 (1975)

21. Schade, D.S., Eaton, R.P.: Modulation of fatty acid metabolism by glucagon in man. Effects in insulin-deficient diabetics. Diabetes 24, 510-515 (1975)

22. Sherwin, R.S., Fisher, M., Hendler, R., Felig, P.: Hyperglucagonaemia and blood glucose regulation in normal, obese and diabetic subjects. New Engl. J. Med. 294, 455-461 (1976)
23. Unger, R.H., Orci, L.: The essential role of glucagon in the pathogenesis of diabetes mellitus. Lancet 1975 I, 14-16

24. Williamson, D.H., Mellanby, J., Krebs, H. A.: Enzymic determination of $\mathrm{D}(-)-\beta$-Hydroxybutyric acid and acetoacetic acid in blood. Biochem. J. 82, 90-96 (1962)

25. Williamson, D.H., Lopes-Vieira, O., Walker, B.: Concentrations of free glucogenic amino acids in livers of rats subjected to various metabolic stresses. Biochem. J. 104, 497-502 (1967)

Received: July 27, 1976, and in revised form: October 26, 1976

Dr. A.J. Barnes

Royal Postgraduate Medical School

Hammersmith Hospital

Du Cane Road

London W12 OHS

England 